\title{
Decreased Particulate NADH Oxidase Activity in Bacillus subtilis Spores After Polymyxin B Treatment
}

\author{
By KUNIO TOCHIKUBO, ${ }^{*}$ YOKO YASUDA AND SATOSHI KOZUKA \\ Department of Microbiology, Nagoya City University Medical School, Nagoya, Aichi 467, Japan
}

(Received 15 May 1985; revised 27 August 1985)

\begin{abstract}
The activities of several enzymes of polymyxin B-treated dormant and germinated spores of Bacillus subtilis were examined. The particulate NADH oxidase of the antibiotic-treated spores showed considerably lower specific and total activities compared with those of untreated ones. The specific and total NADH oxidase activities of untreated spores increased 12- and 15-fold respectively during germination, whereas increases during germination of polymyxin B-treated spores were inhibited. The specific and total activities of particulate NADH cytochrome $c$ reductase of dormant spores were decreased by polymyxin $\mathrm{B}$ treatment in almost the same proportion as those of the particulate NADH oxidase. The specific activity of NADH dehydrogenase of dormant spores remained unchanged after antibiotic treatment but the total activity fell considerably. The activities of other enzymes examined were similar for untreated dormant and germinated spores and antibiotic-treated spores. The respiration of polymyxin Btreated dormant spores was inhibited at the same time as the start of germination. Morphologically, polymyxin B-treated dormant spores lost a laminar structure of the cortex and details of the spore protoplast. The inhibitory mechanism of particulate NADH oxidase activity of polymyxin B-treated dormant spores is discussed.
\end{abstract}

\section{INTRODUCTION}

Cyclic polypeptide antibiotics such as polymyxin B, colistin and gramicidin S, and aminoglycoside antibiotics such as streptomycin, kanamycin and gentamicin bind to the dormant spores of Bacillus subtilis, inhibit outgrowth or vegetative growth after germination, and consequently act as sporocidal or sporostatic agents under certain limited conditions (Tochikubo, 1978; Tochikubo et al., 1981). Morphological changes and macromolecular synthesis during germination, outgrowth, and vegetative growth of the dormant spores treated with the above antibiotics have been investigated in detail (Hayakawa et al., 1981). The electrophoretic mobilities of antibiotic-treated dormant spores have confirmed that cyclic polypeptide and aminoglycoside antibiotics bind at least to the spore coat (Tochikubo, 1978; Tochikubo et al., 1981). However, the inhibitory mechanism for outgrowth and vegetative growth, including the mode of penetration of antibiotics, has not yet been clarified. In order to examine this problem, the activities of some enzymes including particulate NADH oxidase of polymyxin B-treated dormant spores were examined. This report describes the correlation between low particulate NADH oxidase activity and inhibited outgrowth of polymyxin B-treated dormant spores.

\section{METHODS}

Bacterial strain, germination and other procedures. Spores of B. subtilis PCI 219 were used in this study. Spore preparations and treatment with polymyxin $\mathrm{B}$ and colistin were carried out as previously described (Tochikubo $e t$ al., 1981). Antibiotic-treated dormant spores at about $5 \cdot 1 \times 10^{8}$ spores $\mathrm{ml}^{-1}$ were incubated with shaking at $37^{\circ} \mathrm{C}$ for $2 \mathrm{~h}$ in $20 \mathrm{~mm}$-sodium/potassium phosphate buffer $(\mathrm{pH} 7 \cdot 2)$ containing $20 \mathrm{mM}$-L-alanine, washed five times

Abbreviation: DCIP, 2,6-dichlorophenolindophenol. 
with the same buffer, and used as antibiotic-treated germinated spores. Polymyxin B-treated dormant spores were incubated at $37^{\circ} \mathrm{C}$ for $2 \mathrm{~h}$ in sterile $100 \mathrm{~mm}-\mathrm{CaCl}_{2}$ solution (about $3.1 \times 10^{8}$ spores $\mathrm{ml}^{-1}$, final concentration), washed five times with sterile $20 \mathrm{~mm}$-phosphate buffer $\left(\mathrm{pH} \mathrm{7.2)}\right.$, and used as polymyxin B- and $\mathrm{CaCl}_{2}$-treated dormant spores. Subsequently, these spores were also germinated in $20 \mathrm{~mm}$-phosphate buffer $(\mathrm{pH} 7 \cdot 2$ ) containing $20 \mathrm{mM}$-L-alanine. Untreated dormant spores (about $5.1 \times 10^{8}$ spores $\mathrm{ml}^{-1}$ ) were germinated as described above in the presence of $64 \mu \mathrm{g}$ polymyxin $\mathrm{B} \mathrm{ml} \mathrm{m}^{-1}$ or $100 \mu \mathrm{g}$ chloramphenicol $\mathrm{ml}^{-1}$.

Preparation of soluble and particulate fractions. A $10 \mathrm{ml}$ sample of a thick spore suspension (about $10^{11}$ spores

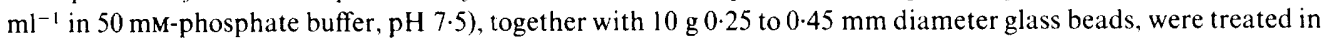
a 20-kc sonic oscillator (Kubota Insonator Model $200 \mathrm{M}$ ) at $2-4{ }^{\circ} \mathrm{C}$ at $1.4 \mathrm{~A}$ and at $160 \mathrm{~W}$ for 30 min for dormant spores and for $10 \mathrm{~min}$ for germinated spores. The broken cell suspension was centrifuged at $10700 \mathrm{~g}$ for $30 \mathrm{~min}$ at $4{ }^{\circ} \mathrm{C}$. The supernatant was centrifuged at $100000 \mathrm{~g}$ for $3 \mathrm{~h}$ at $4{ }^{\circ} \mathrm{C}$ and separated into soluble and particulate fractions; for dormant spores the dipicolinic acid was removed by freezing before ultracentrifugation (Tochikubo \& Yasuda, 1983). The particulate fraction obtained by ultracentrifugation was suspended in a small volume of $50 \mathrm{~mm}$-phosphate buffer ( $\mathrm{pH} 7 \cdot 5$ ). Dormant spores were also sonicated in the presence of various concentrations of polymyxin B dissolved in $50 \mathrm{~mm}$-phosphate buffer $(\mathrm{pH} \mathrm{7.5)}$ and soluble and particulate fractions prepared as described above.

Enzyme assays. Particulate NADH oxidase and soluble NADH oxidase (EC 1.6.99.2) were assayed at $37^{\circ} \mathrm{C}$ by measuring the decrease in absorbance at $340 \mathrm{~nm}$ of $\mathrm{NADH}$ as previously described (Tochikubo, 1971; Tochikubo, 1974); $0 \cdot 3 \mu \mathrm{mol}$ flavine mononucleotide was added to the assay cuvette containing soluble NADH oxidase. The activity of particulate NADH oxidase was also measured after standing at $0{ }^{\circ} \mathrm{C}$ for $4 \mathrm{~h}$ in the presence of various concentrations of polymyxin B. NADH dehydrogenase (EC 1.6.99.3) activity was followed spectrophotometrically at $37^{\circ} \mathrm{C}$ and at $600 \mathrm{~nm}$. The test system contained $1 \mu \mathrm{mol} 2,6$-dichlorophenolindophenol (DCIP), $0.5 \mu \mathrm{mol} \mathrm{KCN}, 0.6 \mu \mathrm{mol} \mathrm{NADH,} \mathrm{30C} \mu \mathrm{mol}$ phosphate buffer ( $\mathrm{pH} 7.5$ ), and 0.01 to $0.05 \mathrm{ml}$ sample. The volume was made up to $3.0 \mathrm{ml}$ in the cuvette $(1 \mathrm{~cm}$ light path) by the addition of deionized water and the reaction was initiated by the addition of NADH. NADH cytochrome $c$ reductase (EC 1.6.99.3) activity was measured at $37^{\circ} \mathrm{C}$ and at $550 \mathrm{~nm}$ in the same manner as $\mathrm{NADH}$ dehydrogenase except that the asssay cuvette contained $0 \cdot 1 \mu \mathrm{mol}$ cytochrome $c$ in place of DCIP. Alanine dehydrogenase (EC 1.4.1.1) and glucose-6-phosphate dehydrogenase (EC 1.1.1.49) were assayed at $37^{\circ} \mathrm{C}$ by measuring NADH and NADPH formation at $340 \mathrm{~nm}$, respectively, as previously described (Nitta et al., 1974; Tanahashi et al., 1976); for glucose-6-phosphate dehydrogenase, $0 \cdot 1 \mu \mathrm{mol} \mathrm{MgCl}_{2}$ was added to the assay cuvette. The activity of alkaline phosphatase (EC 3.1.3.1) was measured according to the method of Glenn \& Mandelstam (1971). Enzyme solution (0.05 ml) was added to $0.6 \mathrm{ml} 25 \mathrm{~mm}$-borate/ $\mathrm{NaOH}$ buffer $(\mathrm{pH} 10 \cdot 0)$ containing $p$-nitrophenyl phosphate and incubated at

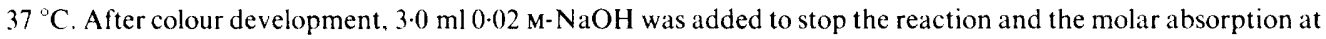
$410 \mathrm{~nm}$ was measured. For catalase (EC 1.11.1.6) enzyme solution $(0.05 \mathrm{ml})$ was added to $0.6 \mathrm{ml} 25 \mathrm{mM}^{-}$ phosphate buffer $\left(\mathrm{pH} \mathrm{7.2)}\right.$ containing $1.5 \%(\mathrm{v} / \mathrm{v}) \mathrm{H}_{2} \mathrm{O}_{2}$ and incubated at $37^{\circ} \mathrm{C}$. After incubation, $3.0 \mathrm{ml} 0.66 \mathrm{M}-$ $\mathrm{H}_{2} \mathrm{SO}_{4}$ was added to stop the reaction and the decrease in absorbance at $250 \mathrm{~nm}$ of $\mathrm{H}_{2} \mathrm{O}_{2}$ was measured (Chance \& Maehly, 1960).

The following molar absorption coefficients were used: $6.22 \mathrm{~mm}^{-1} \mathrm{~cm}^{-1}$ at $340 \mathrm{~nm}$ for NADH and NADPH; $21 \mathrm{~mm}^{-1} \mathrm{~cm}^{-1}$ at $600 \mathrm{~nm}$ for DCIP; and $19 \mathrm{~mm}^{-1} \mathrm{~cm}^{-1}$ at $500 \mathrm{~nm}$ for cytochrome $c$. Each activity was calculated from the linear portion of the time course immediately after the reaction was started.

Protein was determined by the Lowry method.

Microbiological assay of polymyxin B. The polymyxin B released from the antibiotic-treated dormant spores during germination or in $\mathrm{CaCl}_{2}$ solution was measured quantitatively by an antibiotic assay, using the spores of $B$. subtilis as a test organism. A $0.2 \mathrm{ml}$ sample of the spore suspension (about $10^{7}$ spores $\mathrm{ml}^{-1}$ ) was added to $19.8 \mathrm{ml}$ sterile streptomycin agar (Difco), and this was poured into a sterile Petri dish. After solidification, four cups per plate were cut out with a hard steel punch (outs de diameter, $8.6 \mathrm{~mm}$ ). Polymyxin B-treated dormant spores were incubated at $37^{\circ} \mathrm{C}$ for $2 \mathrm{~h}$ in heart infusion broth, in $20 \mathrm{~mm}$-phosphate buffer (pH 7.2) containing $20 \mathrm{~mm}-\mathrm{L}-$ alanine, and in $100 \mathrm{mM}-\mathrm{CaCl}_{2}$ solution, and centrifuged to remove the spores. The supernatant fluid was filtered through a Millipore membrane filter and used as test solution. Polymyxin B dissolved in heart infusion broth, in $20 \mathrm{~mm}$-phosphate buffer ( $\mathrm{pH} \mathrm{7.2)} \mathrm{or} \mathrm{in} 100 \mathrm{mM} \mathrm{CaCl}_{2}$ solution, diluted by a twofold serial dilution method, was used as a standard solution. A $0.15 \mathrm{ml}$ sample of the test or standard solution was pipetted into a cup. After standing at $4{ }^{\circ} \mathrm{C}$ for $15 \mathrm{~h}$ to allow diffusion of polymyxin $\mathrm{B}$, the plate was incubated at $37^{\circ} \mathrm{C}$ for $8 \mathrm{~h}$. The diameter of an inhibitory zone on the surface of the medium was measured with a needle-point caliper.

The amount of polymyxin B in the soluble fractions of polymyxin B-treated dormant and germinated spores, polymyxin $\mathrm{B}$ - and $\mathrm{CaCl}_{2}$-treated dormant spores, and dormant spores sonicated in the presence of various concentrations of polymyxin B was measured as described above. In this case antibiotic dissolved in $20 \mathrm{~mm}-$ phosphate buffer $(\mathrm{pH} \mathrm{7.2)} \mathrm{was} \mathrm{used} \mathrm{as} \mathrm{the} \mathrm{standard} \mathrm{solution.}$

Respiration measurement. Untreated, polymysin B-treated or polymyxin $\mathrm{B}$ - and $\mathrm{CaCl}_{2}$-treated dormant spores were suspended in $50 \mathrm{~mm}$-phosphate buffer $\left(\mathrm{pH} \mathrm{7.2)}\right.$ to give about $5.6 \times 10^{8}$ spores $\mathrm{m}^{-1}$. A $3.6 \mathrm{ml}$ sample of the spore suspension was saturated with $\mathrm{O}_{2}$ by gently bubbling air through the solution. Monitoring of $\mathrm{O}_{2}$ 
consumption was started at the same time as the initiation of germination by the addition of $3 \mu \mathrm{mol} L-\mathrm{alanine}$. $\mathrm{O}_{2}$ consumption was determined at $37^{\circ} \mathrm{C}$ in a stirred cell suspension with a Fieldlab oxygen analyser (Beckman Instruments) in the presence and absence of $0.4 \mu \mathrm{mol} \mathrm{NADH}$. The rate of $\mathrm{O}_{2}$ consumption was continually monitored up to $120 \mathrm{~min}$ and plotted as $\mu$ mol $\mathrm{O}_{2}\left(10^{9} \text { spores }\right)^{-1} \mathrm{ml}^{-1}$ consumed at the indicated time in Fig. $2(b)$.

Electron microscopy. Dormant spores were fixed by the triple-fixation method with a sequential application of $5 \%(\mathrm{v} / \mathrm{v})$ glutaraldehyde, $1 \%(\mathrm{w} / \mathrm{v})$ osmium tetroxide $\left(\mathrm{OsO}_{4}\right)$, and $2 \%(\mathrm{w} / \mathrm{v})$ potassium permanganate as previously described (Kozuka \& Tochikubo, 1983) and suspended in molten $2 \%(w / v)$ agar. After solidification, the agar was cut into $1 \mathrm{~mm}$ cubes. The agar cubes were dehydrated by passage through an ethanol series, substituted by $n$-butyl glycidyl ether, and embedded in Quetol 653 (Kushida, 1980). Germinated spore samples were prefixed in $2.5 \%$ (v/v) glutaraldehyde for $3 \mathrm{~h}$ at $4 \mathrm{C}$ and centrifuged at $1500 \mathrm{~g}$. The pellet was suspended in $1 \mathrm{ml} 1 \%(\mathrm{w} / \mathrm{v}) \mathrm{OsO}_{4}$ and $0.1 \mathrm{ml}$ tryptone medium (Difco) (Kellenberger $e^{\prime} t$ al., 1958) and was fixed overnight at room temperature. After washing with Kellenberger buffer (Kellenberger $e^{\prime}$ al., 1958), the cell pellet was fixed in $0.5 \%(\mathrm{w} / \mathrm{v})$ uranyl acetate and suspended in molten $2 \%(\mathrm{w} / \mathrm{v})$ agar. The agar was cut into $1 \mathrm{~mm}$ cubes and treated as described above. Sections were cut on a Porter-Blum MT ultramicrotome, stained with $6 \%(\mathrm{w} / \mathrm{v})$ uranyl acetate and Reynolds lead citrate (Reynolds, 1963), and examined in a JEOL JEM-200CX electron microscope at an accelerating voltage of $200 \mathrm{kV}$.

Chemicals. NAD, NADP, NADH and glucose 6-phosphate were purchased from Boehringer-Mannheim. Crystalline cytochrome $c$, prepared from Candida krusei, was purchased from Sankyo, polymyxin B sulphate from Sigma, DCIP and $\mathrm{OsO}_{4}$ from Merck, and Quetol 653 from Nisshin EM. All other chemicals were of the finest grade.

\section{RESULTS}

\section{Enzyme activities of antibiotic-treated dormant and germinated spores}

The activities of several enzymes were examined to elucidate the effect of polymyxin B and colistin treatment on dormant and germinated spores. The particulate NADH oxidase of untreated dormant spores showed high specific and total activities, which increased 12- and 15fold respectively during germination (Table 1). Polymyxin B treatment decreased the specific and total activities of particulate NADH oxidase of dormant spores by 70 and $80 \%$, respectively. The specific and total NADH oxidase activities of polymyxin B-treated germinated spores increased to about three and six times those of the corresponding dormant spores and their values were similar to those of untreated dormant spores (Table 1). Treatment with colistin also resulted in a decrease in the specific and total NADH oxidase activities of dormant and germinated spores, but the extent of inhibition was less than that due to polymyxin B treatment

Table 1. Specific and total activities of NADH oxidase and alkaline phosphatase in the particulate fraction of polymyxin B-treated and colistin-treated dormant spores and germinated spores

\begin{tabular}{|c|c|c|c|c|c|}
\hline \multirow[b]{2}{*}{ Enzyme } & \multirow[b]{2}{*}{$\begin{array}{l}\text { Treatment } \\
\text { of spores }\end{array}$} & \multicolumn{2}{|c|}{ Dormant spores } & \multicolumn{2}{|c|}{ Germinated spores } \\
\hline & & $\begin{array}{l}\text { Specific } \\
\text { activity* }\end{array}$ & $\begin{array}{c}\text { Total } \\
\text { activity }\end{array}$ & $\begin{array}{l}\text { Specific } \\
\text { activity* }\end{array}$ & $\begin{array}{c}\text { Total } \\
\text { activity }\end{array}$ \\
\hline NADH oxidase & $\begin{array}{l}\text { Nonet+ } \\
\text { Polymyxin } \mathrm{B} \$ \\
\text { Polymyxin } \mathrm{B} \text {, } \\
\text { incubated with }\end{array}$ & $\frac{262}{74} \pm 59$ & $\begin{array}{r}1417 \\
287\end{array}$ & $\begin{array}{r}3085 \pm 482 \\
225\end{array}$ & $\begin{array}{r}21837 \pm 1845 \\
1747\end{array}$ \\
\hline & $\begin{array}{c}\mathrm{CaCl}_{2} \| \\
\text { Colistin\$ }\end{array}$ & $\begin{array}{l}70 \\
97\end{array}$ & $\begin{array}{l}229 \\
677\end{array}$ & $\begin{array}{r}3094 \\
672\end{array}$ & $\begin{array}{r}16885 \\
5078\end{array}$ \\
\hline Alkaline phosphatase & $\begin{array}{l}\text { Noneł } \\
\text { Polymyxin B\$ } \\
\text { Colistin§ }\end{array}$ & $\begin{array}{r}14 \pm 4 \\
4 \\
5\end{array}$ & $\begin{array}{l}75 \pm 24 \\
14 \\
32\end{array}$ & $\begin{array}{l}16 \pm 3 \\
14 \\
15\end{array}$ & $\begin{array}{l}103 \pm 14 \\
108 \\
115\end{array}$ \\
\hline
\end{tabular}

* Fxpressed as nmol NADH oxidized or $11 \mathrm{~mol} p$-nitrophenylphosphate hydrolysed $\mathrm{min}^{-1}$ (mg protein $)^{-1}$.

$\uparrow$ Expressed as nmol NADH oxidized or $\mu \mathrm{mol} p$-nitrophenylphosphate hydrolysed $\mathrm{min}^{-1}$ per $10^{12}$ spores sonicated.

$\ddagger$ Each value represents the mean of ten determinations \pm SD

$\$$ Fach value represents the mean of five determinations.

if Each value represents the mean of two determinations. 
Table 2. Specific and total activities of particulate NADH oxidase in spores germinated by $L$-alanine in the presence of polymyxin $B$ and chloramphenicol

$\begin{array}{lccc}\text { Antibiotic } & \text { Concn }\left(\mu \mathrm{g} \mathrm{ml}{ }^{-1}\right) & \text { Specific activity* } & \text { Total activity } \\ \text { None } & & 3331 & 20217 \\ \text { Polymyxin B } & 64 & 183 & 1281 \\ \text { Chloramphenicol } & 100) & 2840 & 16798 \\ & & \\ \text { * Expressed as nmol NADH oxidized } \mathrm{min}^{-1}(\mathrm{mg} \text { protein })^{-1} \text {. } \\ \quad+\text { Expressed as nmol NADH oxidized } \mathrm{min}^{-1} \text { per } 10^{12} \text { spores sonicated. }\end{array}$

(Table 1). Calcium treatment after exposure to polymyxin B did not restore either specific or total enzyme activities of dormant spores whereas those of germinated spores were almost completely restored (Table 1).

Spores germinated in the presence of polymyxin B had almost the same specific and total activities of particulate NADH oxidase as those of polymyxin B-treated germinated spores (Tables 1 and 2). The specific and total activities of the spores germinated in the presence of chloramphenicol were about 84 and $85 \%$ of those of untreated germinated spores, respectively (Table 2).

When the particulate fractions from untreated spores were incubated at $0{ }^{\circ} \mathrm{C}$ for $4 \mathrm{~h}$ in the presence of polymyxin B, the activity of particulate NADH oxidase fell to a similar value for both dormant and germinated spores as the concentration of antibiotic increased (Fig. 1).

The specific and total activities of alkaline phosphatase in the particulate fraction of polymyxin B- and colistin-treated dormant spores were lower than those of untreated ones, but in germinated spores the enzyme showed almost similar specific and total activities regardless of polymyxin B or colistin treatment (Table 1).

The specific and total activities of catalase, NADH oxidase, alanine dehydrogenase and glucose-6-phosphate dehydrogenase in the soluble fractions of dormant and germinated spores exhibited little or no differences after polymyxin B or colistin treatment except that the soluble fraction from polymyxin B- and colistin-treated germinated spores had about one-half the specific and total activities of alanine dehydrogenase compared with that of untreated germinated spores (Table 3).

\section{Comparison of particulate NADH oxidase, NADH dehydrogenase and NADH cytochrome c reductase activities}

The extent of the decrease in specific and total activities of NADH oxidase in the particulate fraction of polymyxin B-treated dormant spores corresponded more to that of the specific and total activities of NADH cytochrome $c$ reductase than to that of NADH dehydrogenase (Table 4). The same result was obtained also with polymyxin $\mathrm{B}$ - and $\mathrm{CaCl}_{2}$-treated dormant spores (Table 4), with dormant spores sonicated in the presence of 7 or $10 \mathrm{mg}$ polymyxin B (Table 4), and with polymyxin B-treated germinated spores (data not shown). The specific activity of NADH dehydrogenase of dormant spores was not significantly affected by polymyxin $B$ treatment (Table 4).

As can be calculated from Table 4, the protein content in the particulate fraction of polymyxin B-treated dormant spores was considerably lower than that of untreated spores and the protein content of the particulate fraction of dorrnant spores sonicated in the presence of polymyxin $B$ decreased as the concentration of the antibiotic was increased.

\section{Quantity of polymyxin B in the soluble fraction}

A microbiological assay was carried out to investigate the total amount of polymyxin B released during sonication into the soluble fractions of polymyxin B- and polymyxin B- and $\mathrm{CaCl}_{2}$-treated dormant spores and polyrnyxin $\mathrm{B}$-treated germinated spores. Whereas about $860 \mu \mathrm{g}$ polymyxin $\mathrm{B}$ (which was similar to that of the dormant spores sonicated in the presence of $10 \mathrm{mg}$ polymyxin $\mathrm{B}$ ) were released into the soluble fraction of polymyxin B-treated dormant 


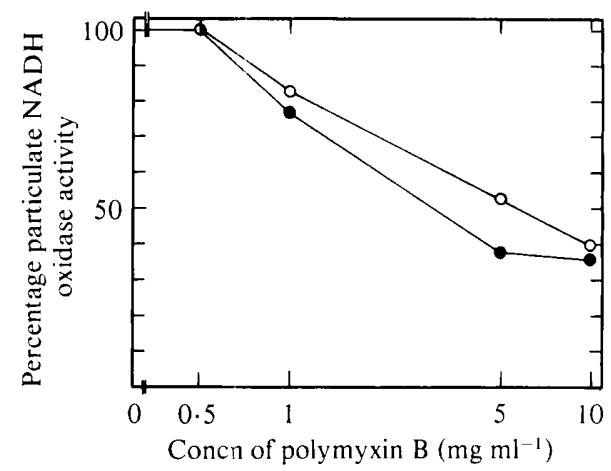

Fig. 1. Effect of polymyxin B on the activity of particulate NADH oxidase from untreated dormant (O) and germinated $(O)$ spores of $B$. subtilis. The enzyme activity was measured after incubation at $0{ }^{\circ} \mathrm{C}$ for $4 \mathrm{~h}$ in the presence of various concentrations of polymyxin $\mathrm{B}$.

Table 3. Specific and total activities of catalase, NADH oxidase, alanine dehydrogenase, and glucose-6-phosphate dehydrogenase in the soluble fraction of polymyxin B-treated and colistin-treated dormant spores and germinated spores

\begin{tabular}{|c|c|c|c|c|c|}
\hline \multirow[b]{2}{*}{ Enzyme } & \multirow[b]{2}{*}{$\begin{array}{l}\text { Treatment } \\
\text { of spores }\end{array}$} & \multicolumn{2}{|c|}{ Dormant spores } & \multicolumn{2}{|c|}{ Germinated spores } \\
\hline & & $\begin{array}{l}\text { Specific } \\
\text { activity* }\end{array}$ & $\begin{array}{l}\text { Total } \\
\text { activity }\end{array}$ & $\begin{array}{l}\text { Specific } \\
\text { activity* }\end{array}$ & $\begin{array}{l}\text { Total } \\
\text { activity }\end{array}$ \\
\hline Catalase & $\begin{array}{l}\text { None } \ddagger \\
\text { Polymyxin B§} \\
\text { Colistin§ }\end{array}$ & $\begin{array}{l}21 \pm 4 \\
19 \\
24\end{array}$ & $\begin{array}{l}351 \pm 62 \\
430 \\
554\end{array}$ & $\begin{array}{l}46 \pm 7 \\
30 \\
51\end{array}$ & $\begin{array}{l}881 \pm 82 \\
422 \\
740\end{array}$ \\
\hline NADH oxidase & $\begin{array}{l}\text { None } \neq \\
\text { Polymyxin B } \S \\
\text { Colistin } \S\end{array}$ & $\begin{array}{l}200 \\
139 \\
135\end{array}$ & $\begin{array}{l}3461 \pm 541 \\
2807 \\
3150\end{array}$ & $\begin{array}{l}156 \pm 20 \\
187 \\
222\end{array}$ & $\begin{array}{l}2726 \pm 280 \\
2842 \\
3276\end{array}$ \\
\hline $\begin{array}{l}\text { Alanine } \\
\text { dehydrogenase }\end{array}$ & $\begin{array}{l}\text { None } \ddagger \\
\text { Polymyxin } \mathrm{B} \S \\
\text { Colistin } \S\end{array}$ & $\begin{array}{r}118 \pm 37 \\
68 \\
63\end{array}$ & $\begin{array}{l}2112 \pm 427 \\
1514 \\
1457\end{array}$ & $\begin{array}{l}521 \pm 160 \\
232 \\
235\end{array}$ & $\begin{array}{l}8908 \pm 1171 \\
3570 \\
3430\end{array}$ \\
\hline $\begin{array}{l}\text { Glucose-6- } \\
\text { phosphate } \\
\text { dehydrogenase }\end{array}$ & $\begin{array}{l}\text { None } \ddagger \\
\text { Polymyxin } B \S \\
\text { Colistin } \S\end{array}$ & $\begin{array}{l}297 \pm 75 \\
215 \\
220\end{array}$ & $\begin{array}{l}5288 \pm 726 \\
4859 \\
5115\end{array}$ & $\begin{array}{l}363 \pm 114 \\
474 \\
514\end{array}$ & $\begin{array}{l}6357 \pm 724 \\
7331 \\
7588\end{array}$ \\
\hline
\end{tabular}

spores, no detectable concentration of the antibiotic was released from polymyxin $\mathrm{B}$ - and $\mathrm{CaCl}_{2}-$ treated ones. The soluble fraction of polymyxin B-treated germinated spores contained about $290 \mu \mathrm{g}$ polymyxin B. When dormant spores were sonicated in the presence of various concentrations of the antibiotic, no detectable concentration of antibiotic was present in the soluble fractions from dormant spores sonicated at $\leqslant 5 \mathrm{mg}$ polymyxin $\mathrm{B}$.

Quantity of polymyxin $\mathrm{B}$ released during germination and by treatment with $\mathrm{CaCl}_{2}$

The amount of antibiotic removed from polymyxin B-treated dormant spores during germination and by treatment with $\mathrm{CaCl}_{2}$ was determined. Approximately $2 \cdot 1 \times 10^{8}$ spores 
Table 4. Specific and total activities of $N A D H$ oxidase, $N A D H$ dehydrogenase and NADH cytochrome $c$ reductase in the particulate fractions of polymyxin $B$-treated and polymyxin $B$-and $\mathrm{CaCl}_{2}$-treated dormant spores and dormant spores sonicated in the presence of tarious concentrations of polymyxin $B$

Specific activity is expressed as nmol NADH oxidized, nmol 2,6-dichlorophenolindophenol reduced or nmol cytochrome $c$ reduced $\mathrm{min}^{-1}(\mathrm{mg} \text { protein })^{-1}$. Total activity is expressed as nmol NADH oxidized, nmol 2,6-dichlorophenolindophenol recuced or nmol cytochrome $c$ reduced $\mathrm{min}^{-1}$ per $10^{12}$ spores sonicated. Each value represents the mean of two determinations. Numbers in parentheses show percentage of activity expressed as activity of polymyxin B-treated and polymyxin $\mathrm{B}$ - and $\mathrm{CaCl}_{2}$-treated dormant spores and dormant spores sonicated in the presence of polymyxin B divided by activity of untreated spores.

\begin{tabular}{|c|c|c|c|c|c|c|c|c|c|}
\hline \multirow[b]{3}{*}{ Enzyme } & \multirow[b]{3}{*}{ Activity } & \multicolumn{3}{|c|}{ Treatment of dormant spores } & \multicolumn{5}{|c|}{$\begin{array}{c}\text { Dormant spores (about } 10^{12} \text { ) sonicated in } \\
\text { the presence of polymyxin } B\end{array}$} \\
\hline & & & & Polymyxin B & & Poly & yxin ( & & \\
\hline & & None & Polymyxin B & and $\mathrm{CaCl}_{2}$ & 1 & 3 & 5 & 7 & 10 \\
\hline \multirow[t]{2}{*}{$\begin{array}{l}\text { NADH } \\
\text { oxidase }\end{array}$} & Specific & $\begin{array}{l}263 \\
(100)\end{array}$ & $\begin{array}{l}08 \\
(i 7)\end{array}$ & $\begin{array}{c}86 \\
(33)\end{array}$ & $\begin{array}{l}291 \\
(111)\end{array}$ & $\begin{array}{c}270 \\
(103)\end{array}$ & $\begin{array}{l}265 \\
(101)\end{array}$ & $\begin{array}{l}114 \\
(43)\end{array}$ & $\begin{array}{l}91 \\
(35)\end{array}$ \\
\hline & Total & $\begin{array}{l}1688 \\
(100)\end{array}$ & $\begin{array}{l}2<4 \\
(14)\end{array}$ & $(16)$ & $\begin{array}{c}1647 \\
(98)\end{array}$ & $\begin{array}{l}1744 \\
(103)\end{array}$ & $\begin{array}{c}1304 \\
(77)\end{array}$ & $\begin{array}{l}267 \\
(16)\end{array}$ & $\begin{array}{l}244 \\
(14)\end{array}$ \\
\hline \multirow[t]{2}{*}{$\begin{array}{l}\text { NADH } \\
\text { dehydrogenase }\end{array}$} & Specific & $\begin{array}{l}2184 \\
(100)\end{array}$ & $\begin{array}{r}2042 \\
(93)\end{array}$ & $\begin{array}{l}1595 \\
(73)\end{array}$ & $\begin{array}{c}2456 \\
(112)\end{array}$ & $\begin{array}{l}2270 \\
(104)\end{array}$ & $\begin{array}{l}2227 \\
(102)\end{array}$ & $\begin{array}{r}1934 \\
(89)\end{array}$ & $\begin{array}{r}1681 \\
(77)\end{array}$ \\
\hline & Total & $\begin{array}{r}14021 \\
(100)\end{array}$ & $\begin{array}{l}5085 \\
(36)\end{array}$ & $\begin{array}{r}4984 \\
(36)\end{array}$ & $\begin{array}{r}13901 \\
(99)\end{array}$ & $\begin{array}{r}14664 \\
(105)\end{array}$ & $\begin{array}{r}10597 \\
(76)\end{array}$ & $\begin{array}{r}4522 \\
(32)\end{array}$ & $\begin{array}{r}4505 \\
(32)\end{array}$ \\
\hline \multirow{2}{*}{$\begin{array}{l}\text { NADH } \\
\text { cytochrome } c \\
\text { reductase }\end{array}$} & Specific & $\begin{array}{c}88 \\
(100)\end{array}$ & $\begin{array}{c}38 \\
(43)\end{array}$ & $\begin{array}{c}27 \\
(31)\end{array}$ & $\begin{array}{c}87 \\
(99)\end{array}$ & $\begin{array}{c}76 \\
(86)\end{array}$ & $\begin{array}{c}71 \\
(81)\end{array}$ & $\begin{array}{c}45 \\
(51)\end{array}$ & $\begin{array}{c}28 \\
(32)\end{array}$ \\
\hline & Total & $\begin{array}{c}565 \\
(100)\end{array}$ & $\begin{array}{c}95 \\
(17)\end{array}$ & $\begin{array}{c}84 \\
\text { (15) }\end{array}$ & $\begin{array}{l}492 \\
(87)\end{array}$ & $\begin{array}{l}491 \\
(87)\end{array}$ & $\begin{array}{l}349 \\
(62)\end{array}$ & $\begin{array}{l}105 \\
(19)\end{array}$ & $\begin{array}{c}75 \\
\text { (13) }\end{array}$ \\
\hline
\end{tabular}

$\mathrm{ml}^{-1}$ in heart infusion broth or in $100 \mathrm{~mm}$-phosphate buffer $(\mathrm{pH} \mathrm{7.2)}$ containing $20 \mathrm{~mm}-\mathrm{L}-$ alanine (the physiological germinant for $B$. subtilis spores) released no detectable concentration of polymyxin $\mathrm{B}$, but in $100 \mathrm{~mm}-\mathrm{Tris} / \mathrm{HCl}$ buffer $(\mathrm{pH} 7 \cdot 5)$ containing $100 \mathrm{~mm}-\mathrm{CaCl}_{2}$ about $3.3 \mu \mathrm{g}$ $\mathrm{ml}^{-1}$ was released. However, this concentration was about one-quarter of the minimum inhibitory concentration (MIC; $12.5 \mu \mathrm{g} \mathrm{ml}^{-1}$; Tochikubo et al., 1981) for the same number of dormant spores. When 2.4 times the number of polymyxin B-treated dormant spores $\left(5.1 \times 10^{8}\right.$ spores $\mathrm{ml}^{-1}$ ) were incubated in heart infusion broth or in $20 \mathrm{~mm}$-L-alanine, 5.3 and $6.1 \mu \mathrm{g}$ polymyxin $\mathrm{B} \mathrm{ml} \mathrm{ml}^{-1}$ were released. These values represent one-quarter to one-fifth of the MIC $\left(25 \mu \mathrm{g} \mathrm{ml}^{-1}\right)$ for the same number of dormant spores. In $100 \mathrm{mM}-\mathrm{CaCl}_{2}$ solution they released $10 \mu \mathrm{g}$ polymyxin $\mathrm{B} \mathrm{ml} \mathrm{m}^{-1}$, which was less than one-half of the MIC.

\section{Respiration during germination of polymyxin B-treated dormant spores}

Although the germination rate was slightly stimulated compared with untreated dormant spores (Fig. $2 a$ ), the respiration of polymyxin B-treated dormant spores was inhibited at the same time as the start of germination and the inhibition of respiration after $120 \mathrm{~min}$ was more than $90 \%$ (Fig. $2 b$ ). Subsequent treatment with $\mathrm{CaCl}_{2}$ before germination restored the respiration of polymyxin B-treated dormant spores to that of untreated spores (Fig. $2 b$ ). Similar results were also obtained in the absence of NADH (data not shown).

\section{Morphological changes of polymyxin B-treated dormant and germinated spores}

The majority of untreated dormant spores demonstrated a laminar cortex and a spore protoplast with a clear roundish germ cel wall and granules (Fig. $3 a$ ), whereas a considerable number of polymyxin B-treated dormant spores lost structural details of the cortex and the spore protoplast, and moreover, the latter was irregular in form (Fig. 3 b). Insufficient infiltration of resins was also observed.

The untreated germinated spores $2 \mathrm{~h}$ after incubation in $20 \mathrm{~mm}$-L-alanine solution showed a thinness of the spore coat, a diminution in size of the cortex, a swollen core, a cell wall, some 

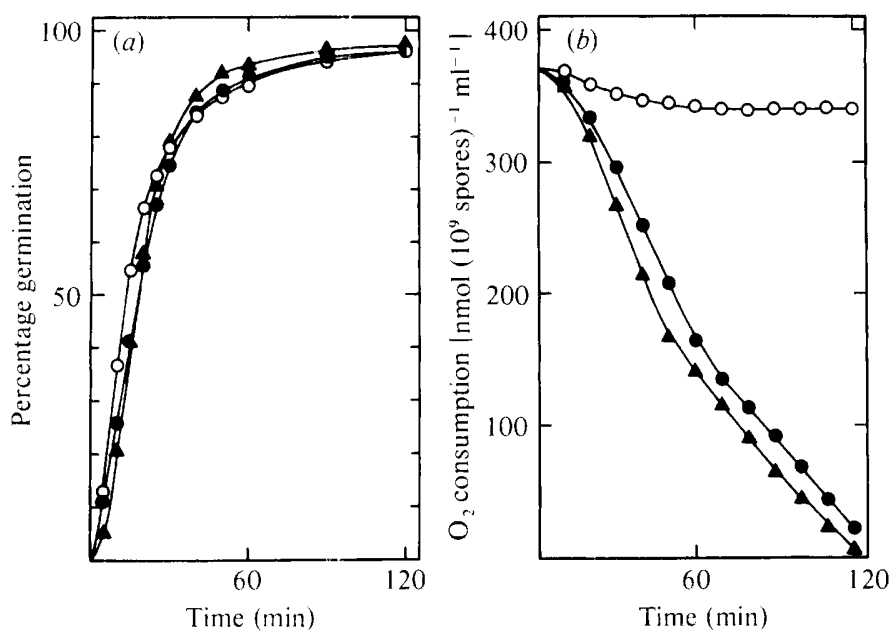

Fig. 2. Time course of L-alanine-initiated germination $(a)$ and respiration during germination $(b)$ of polymyxin B-treated dormant spores. Germination experiments were done by incubation of dormant spores (about $2 \times 10^{8}$ cells $\mathrm{ml}^{-1}$ ) at $37^{\circ} \mathrm{C}$ in $3 \mathrm{ml} 50 \mathrm{~mm}$-phosphate buffer ( $\mathrm{pH} 7 \cdot 2$ ) containing $3 \mu \mathrm{mol}$ L-alanine. Germination was measured by loss of optical density of the spore suspension and is expressed as a percentage of the reduction in $\mathrm{OD}_{650}$ determined with a Bausch \& Lomb Spectronic $20 \mathrm{~A}$ spectrophotometer by the method of Hachisuka et al. (1955). See text for details of respiration measurement. Untreated dormant spores; $\bigcirc$, polymyxin B-treated spores: $\mathbf{A}$, polymyxin B-and $\mathrm{CaCl}_{2}$-treated spores.

mesosomes and DNA fibrils (Fig. $4 a$ ). Fig. $4(b)$ shows a thin section of the germinated spores derived from polymyxin B-treated dormant spores after incubation for $2 \mathrm{~h}$ in $20 \mathrm{~mm}$-L-alanine solution. The spore core appears irregular in form and the thin cell wall was detached from the cytoplasmic membrane in some places. Moreover, the cytoplasm was densely homogeneous and not granular, and the nuclear material was not visible. These features are in agreement with those of the germinated spores derived from polymyxin B-treated dormant spores after incubation for 3 and $24 \mathrm{~h}$ in heart infusion broth (Hayakawa et al., 1981).

Electron micrographs of the spores germinated in the presence of chloramphenicol and polymyxin B resembled those of untreated germinated spores and polymyxin B-treated ones, respectively (data not shown).

\section{DISCUSSION}

The basic polypeptide antibiotic polymyxin B kills bacteria by interaction with the cytoplasmic membrane (Few, 1955; Newton, 1956; Storm et al., 1977). The mode of action may be an irreversible breakdown of the permeability barrier of the membrane (Imai et al., 1975).

The activity of particulate NADH oxidase of polymyxin B-treated dormant spores was considerably lower when compared with that of untreated ones, and the antibiotic treatment inhibited the remarkable increase in particulate NADH oxidase activity during germination (Table 1) as well as growth after germination (Tochikubo et al., 1981; Hayakawa et al., 1981). Although the enzyme activity of polymyxin $\mathrm{B}$ - and $\mathrm{CaCl}_{2}$-treated dormant spores was inhibited to the same extent as that of polymyxin B-treated spores (Tables 1 and 4), they recovered the growth ability after germination (Tochikubo et al., 1981). It is therefore necessary to distinguish between the effect of polymyxin B on enzyme activity and that of the antibiotic on growth after germination. Polymyxin B treatment clearly has direct or indirect effects upon the membranous structure of dormant spores which is the site of the electron transport chain and oxidative phosphorylation. At least two possibilities can be considered with regard to the inhibitory mechanism of particulate NADH oxidase activity of polymyxin B-treated dormant spores. The 

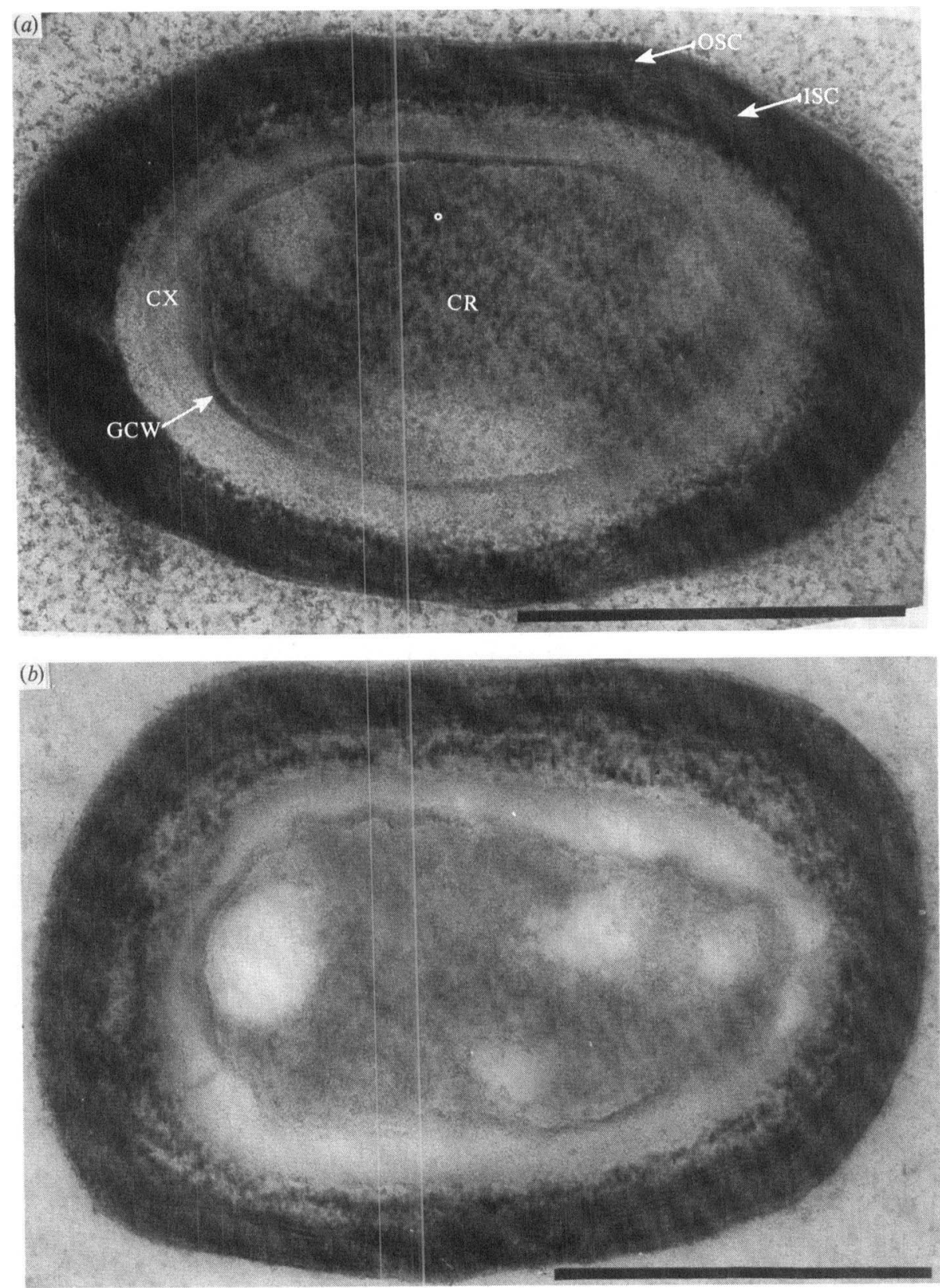

Fig. 3. Flectron micrographs of thin sections of untreated $(a)$ and polymyxin B-treated $(b)$ dormant spores of B. subtilis. OSC, outer spore coat: ISC, inner spore coat: CX, cortex: GCW, germ cell wall; CR, core. Bars represent $0.5 \mu \mathrm{m}$.

first possibility is that polymyxin B not only binds to the spore coat (Tochikubo et al., 1981) but can also penetrate to the inner cytoplasmic membrane, leading to the inhibition of respiration. However, since treatment of polymyxin 13 -treated dormant spores with $\mathrm{CaCl}_{2}$ reversed the inhibitory effect of the antibiotic on grcwth (Tochikubo et al., 1981) and the activity of particulate NADH oxidase from their germinated spores was almost the same as that from untreated spores (Table 1), it is considerec that an irreversible breakdown of the cytoplasmic 

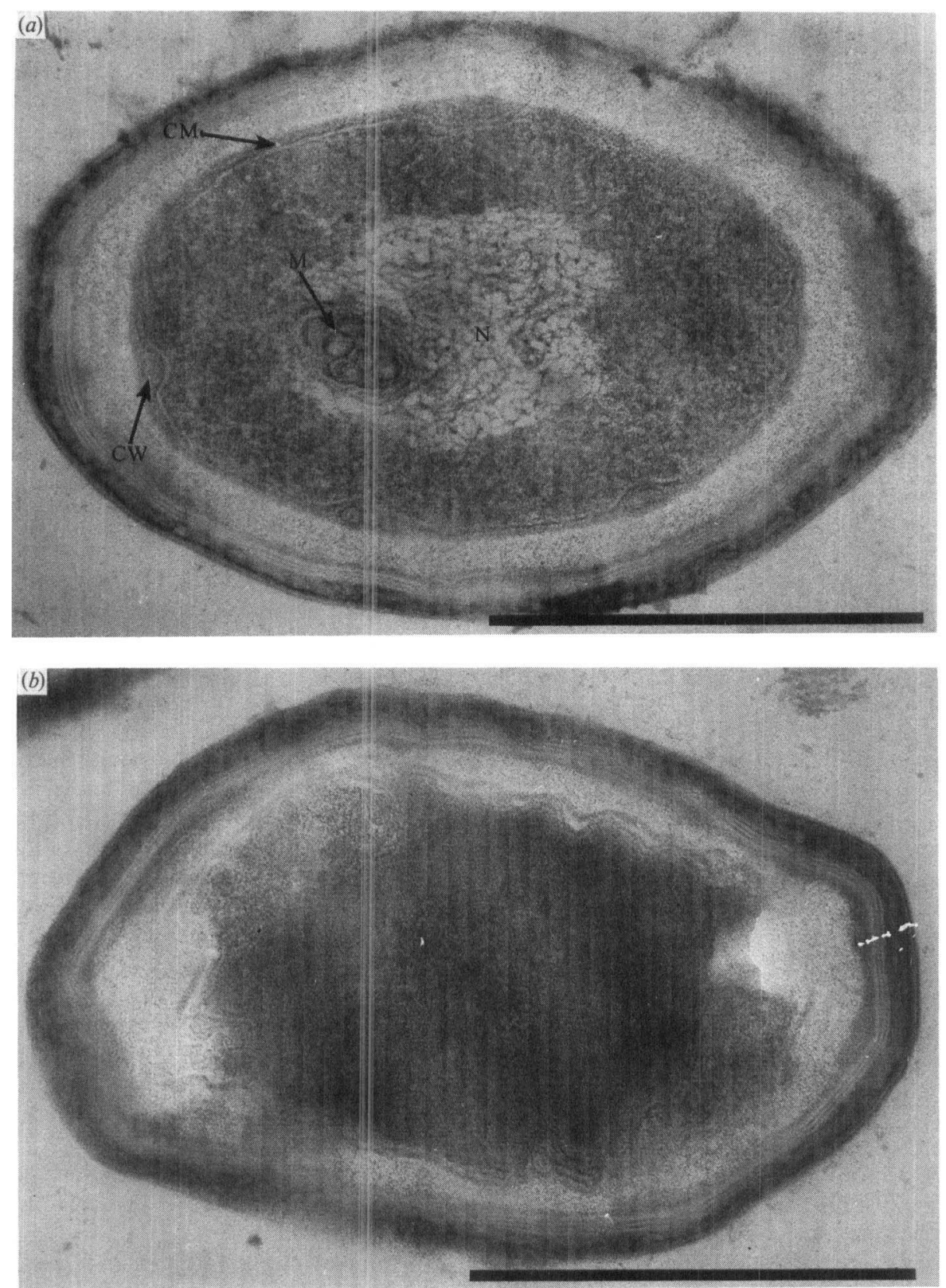

Fig. 4. Electron micrographs of thin sections of untreated $(a)$ and polymyxin B-treated $(b)$ germinated spores of B. subtilis. CW, cell wall; CM, cytoplasmic membrane; M, mesosome; N, fibrillar nucleoid. Bars represent $0.5 \mu \mathrm{m}$.

membrane did not occur by treatment with the antibiotic. Therefore the antibiotic is not able to reach the cytoplasmic membrane of dormant spores. The second possibility is that interaction of polymyxin B with the outer pericortex membrane of dormant spores can affect the cytoplasmic membrane in some way to inhibit respiration without binding directly to the membrane. In Escherichia coli and Pseudomonas aeruginosa perturbation of the outer membrane structure by immobilized polymyxin can indirectly affect bacterial growth and respiration without direct 
interaction of the antibiotic with the cytoplasmic membrane (LaPorte et al., 1977). The existence of an outer membrane in the dormant spores of Bacillus megaterium has been demonstrated biochemically since the isolated outer integument contains cytochromes, electron transport enzymes and polypeptides (Cra ts-Lighty \& Ellar, 1980) and by the morphological observation of variant spores lacking exosporium (Koshikawa et al., 1984). Accordingly, the second possibility seems most likely. The unclear structure and irregular form of the protoplast of polymyxin B-treated dormant spores (Fig. $3 b$ ) may be due to unsufficient infiltration of fixatives caused by perturbation of the outer membrane. In this case, although the disorder of the outer membrane by polymyxin B does not seem to be recoverable, the cytoplasmic membrane appears to bear the antibiotic damage because of complete reversion of both particulate NADH oxidase activity (Table 1 ) and $\mathrm{O}_{2}$ consumption (Fig. $2 b$ ) during germination of polymyxin $\mathrm{B}$ - and $\mathrm{CaCl}_{2}$-treated dormant spores.

Addition of $\mathrm{CaCl}_{2}$ to polymyxin $\mathrm{B}$-treated dormant spores reverses the electrophoretic mobility within the normal range by relecsing the antibiotic bound to the spore coat surface (Tochikubo et al., 1981). Since $10 \mu \mathrm{g}$ polymyxin B is released from about $5 \cdot 1 \times 10^{8}$ spores, about $20 \mathrm{mg}$ polymyxin $\mathrm{B}$ will be released from $10^{12}$ polymyxin B-treated dormant spores by treatment with $100 \mathrm{~mm}-\mathrm{CaCl}_{2}$. No detectable concentration of the antibiotic was found in the soluble fraction of polymyxin $\mathrm{B}$ - and $\mathrm{CaCl}_{2}$-treated dormant spores and therefore the total amount of the antibiotic binding to $10^{12}$ spores after $\mathrm{CaCl}_{2}$ treatment is $\leqslant 5 \mathrm{mg}$. It seems probable that about $20 \mathrm{mg}$ polymyxin $\mathrm{B}$ binds to the spore coat and can be easily dissociated by treatment with $\mathrm{CaCl}_{2}$, whereas a small quantity ( $5 \mathrm{mg}$ and less) of the antibiotic binds to the outer pericortex membrane and cannot be dissociated by $\mathrm{CaCl}_{2}$ treatment. Thus the low activity of particulate NADH oxidase of polymyxin $\mathrm{B}$ - and $\mathrm{CaCl}_{2}$-treated dormant spores may be due to the inhibitory effect of a small amount of the antibiotic binding to the outer pericortex membrane.

The low activity of particulate NADH oxidase (Table 1) and the inhibited outgrowth of polymyxin B-treated germinated spores ('Tochikubo et al., 1981) could be due to antibiotic released from the spore coat during germination. It seems that germinating spores directly incorporate the released antibiotic into the inside, since about $89 \%$ of the polymyxin B-treated dormant spores are not able to form colonies on heart infusion agar plates (Tochikubo et al., 1981) and the respiration of polymyxin B-treated dormant spores was inhibited at the same time as the start of germination (Fig. $2 b$ ). The recovery of growth ability of polymyxin $\mathrm{B}$ - and $\mathrm{CaCl}_{2}-$ treated dormant spores may be due to the removal of bound antibiotic.

The inhibitory action of polymyxin Bi on the activity of particulate NADH oxidase may occur during spore fractionation. However, the following two facts support our opinion that inhibition of the enzyme activity by polymyxin B occurs before spore fractionation: (i) in spite of very low specific and total enzyme activities, the soluble fraction of polymyxin $\mathrm{B}$ - and $\mathrm{CaCl}_{2}$-treated dormant spores contained no detectable concentration of the antibiotic; (ii) inhibition of respiration of polymyxin B-treated dormant spores occurred at the same time as the initiation of germination (Fig. 2b).

The decrease in the specific and total activities of particulate NADH oxidase by polymyxin B treatment agreed well with those for NADH cytochrome $c$ reductase activities but not with those for NADH dehydrogenase activities (Table 4). The specific activity of NADH dehydrogenase after polymyxin B treatment was almost in agreement with that of untreated dormant spores, but about $64 \%$ of the total enzyme activity was lost (Table 4 ). This loss originated in the decrease in the protein content from the particulate fraction of polymyxin B-treated dormant spores. If the protein content of the latter is corrected to the same protein content as that of untreated spores in Table $4,93 \%$ of the total enzyme activity was recovered. This suggests that there is little or no decrease in the total activity of NADH dehydrogenase by a specific action of polymyxin $\mathrm{B}$ on the enzyme. The site inhibited by the antibiotic in the electron transport chain seems to be between coenzyme $\mathrm{Q}$ and cytochrome $c$.

The protein content of the particulate fraction of polymyxin B-treated dormant spores decreased by approximately one-half compared with that of untreated spores, and sonication of dormant spores in the presence of polymyxin $\mathrm{B}$ also decreased the protein content in particulate fractions depending on the antibiotic concentration (Tables 1 and 4). A high concentration of 
polymyxin B may therefore damage membranous structures and induce solubilization of membrane-bound proteins during fractionation even at low temperature. The decrease in total activities of particulate NADH oxidase and NADH cytochrome $c$ reductase by polymyxin B treatment is therefore caused both by the decrease in the specific activities of the enzymes and by that in the particulate protein content.

Wilkinson et al. (1977) have reported that a rapid chloramphenicol-resistant activation of certain membrane-bound respiratory chain enzymes occurs in the first $10 \mathrm{~min}$ of germination of $B$. megaterium $\mathrm{KM}$ spores. The same phenomenon was observed also with the particulate NADH oxidase of $B$. subtilis spores (Table 2).

We are grateful to Dr Roy H. Doi, Department of Biochemistry and Biophysics, University of California, Davis, USA, for his review and valuable criticism of the manuscript.

\section{REFERENCES}

Chance, B. \& MaEhly, A. C. (1960), Assay of catalases and peroxidases. Methods in Enzymology 2 , 764-775

Crafts-Lighty. A. \& Ellar, D. J. (1980). The structure and function of the spore outer membrane in dormant and germinating spores of Bacillus megaterium. Journal of Applied Bacteriology 48, 135-145.

FEw, A. V. (1955). The interaction of polymyxin $E$ with bacterial and other lipids. Biochimica et biophisica acta 16, 137--145.

Glenn, A. R. \& Mandelstam, J. (1971). Sporulation in Bacillus subtilis 168. Comparison of alkaline phosphatase from sporulating and vegetative cells. Biochemical Journal 123, 129-138.

Hachislka, Y.. Asano, N., Kato, N., OkaJima, M., Kitaori, M. \& KUnO, T. (1955). Studies on spore germination. I. Effect of nitrogen sources on spore germination. Journal of Bacteriology 69, 39 -406 .

Hayakawa, Y., Tochikubo, K. \& Kozlka, S. (1981). Mutual relationship between antibiotics and resting spores of Bacillus subtilis: morphological changes and macromolecular synthesis after germination of spores treated with cyclic polypeptide and aminoglycoside antibiotics. Microbiology and Immunology 25, 655-670.

IMAI, M. INole, K. \& NoJma, S. (1975). Fiffect of polymyxin $B$ on liposomal membranes derived from Escherichia coli lipids. Biochimica et biophysica acta 375, 130137

Kellenberger, F, Ryter, A. \& Sechaud, I. (1958). Electron microscope study of DNA-containing plasms. II. Vegetative and mature phage DNA as compared with normal bacterial nucleoids $\mathrm{n}$ different physiological states. Journal of Biophysical and Biochemical clologg! 4,671678.

Koshikawa. T., Bfaman, T. C., Pankrat $z$, H. S., Nakashio, S., Corner, T. R. \& (jerhardt, P. (1984). Resistance, germination, and permeability correlates of Bacillus megaterium spores successively divested of integument layers. Journal of Bacteriolog.' 159, 624.632.

KozUKa, S. \& Tochikubo, K. (1983). Triple fixation of Bacillus subtilis dormant spores. Journalof Bacterio$\log y^{156}, 409-413$.

KusHiDA, H. (1980). An improved embedding method using FRL 4206 and Quetol 65.3. Journal of Electron Microscoply 29. 193194

laporte, D. ('. Rosenthal. K. S. \& Storm, D. R.
(1977). Inhibition of Escherichia coli growth and respiration by polymyxin $\mathrm{B}$ covalently attached to agarose beads. Biochemistry 16, 1642-1648.

NewTon, B. A. (1956). The properties and mode of action of the polymyxins. Bacteriological Reviews $\mathbf{2 0}$, $14 \cdot 27$.

NitTa, Y., Yaslda, Y. Tochikubo, K. \& Hachislka, Y. (1974). L-Amino acid dehydrogenases in Bacillus subtilis spores. Journal of Bacteriology 117, 588-592.

REYNOLDS, E. S. (1963). The use of lead citrate at high $\mathrm{pH}$ as an electron-opaque stain in electron microscopy. Journal of Cell Biology 17, 208-212.

Storm, D. R., Rosenthal, K. S. \& Swanson, P. F. (1977). Polymyxin and related peptide antibiotics. Annual Reviews in Biochemistry 46, 723-763.

Tanahashi, T., Tochikubo, K. \& Hachislika. Y. (1976). Purification and properties of glucose-6phosphate dehydrogenase from Bacillus subtilis spores. Japanese Journal of Microhiology 20.281 286.

Toснікuво, K. (1971). Changes in terminal respiratory pathways of Bacillus subtilis during germination, outgrowth, and vegetative growth. Journal of Bacteriolog! 108, 652-661

Tochikubo, K. (1974). $\alpha-\alpha^{\prime}$-Dipyridyl or ortho-phenanthroline stimulation of the soluble reduced nicotinamide adenine dinucleotide oxidase from Bacillus subtilis spores and dipicolinic acid inhibition of the stimulated enzyme. Journal of Bacteriology 117, $1017-1022$.

Tochikubo, K. (1978). Outgrowth and vegetative growth inhibition of Bacillus subtilis spores after transient exposure to polymyxin B. Journal of Bacteriology 134, 680-682.

Tochikubo, K. \& Yasuda, Y. (1983). Fffect of disruption by sonication under different conditions on the activity of glucose dehydrogenase from resting spores of Bacillus subtilis. Microbiology and Immunology 27, 733-748.

Tochikubo, K., Hayakawa, Y. \& Kojima, K. (1981). Mutual relationship between antibiotics and resting spores of Bacillus subtilis: binding of cyclic polypeptide and aminoglycoside antibiotics to spores and their inhibitory effect on outgrowth and vegetative growth. Microbiology and Immunology 25, 113-126.

Wilkinson, B. J., Ellar, D. J., SCott, I. R. \& KONCEWICZ, M. A. (1977). Rapid, chloramphenicolresistant, activation of membrane electron transport on germination of Bacillus spores. Nature, London 266, $174 \cdot 176$. 